\title{
Congenital heart disease in male and female subjects with somatic features of Turner's syndrome and normal sex chromosomes (Ullrich's and related syndromes)
}

\author{
D. C. Siggers, and Paul E. Polani (Co-author with Dr. Campbell of papers on aetiology of \\ iongenital heart disease) \\ From the Paediatric Research Unit, Guy's Hospital Medical School, London
}

The distribution of types of congenital heart disease in male and female subjects with the somatic eatures of Turner's syndrome, but normal chromosomes (Ullrich's syndrome in males and females; Turner's syndrome in males), is reported. Detailed information was derived from cardiac cathterization, operation, and necropsy findings in 44 published cases and 22 new cases. The disribution of types of congenital heart disease in the 22 new patients is compared with a group of matched patient controls with congenital heart disease. Pulmonary valve stenosis is much more frequent in the patients with 'Turner-like' syndrome and normal chromosomes, and in the controls it is often associated with primum atrial septal defect. Other lesions that occurred more commonly than in the control group were persistent ductus arteriosus, anomalous pulmonary venous drainage, coarctation of the aorta (though not as frequently as in $45, X$ Turner's syn(rome), and hypertrophic obstructive cardiomyopathy. Lesions less frequent in the 'Turner-like' group were ventricular septal defect, Fallot's tetralogy, valvar aortic stenosis, and complete transposition of the great vessels.

In 1938, Turner described a syndrome of short stature, webbing of the neck, cubitus valgus, and sexual and skeletal infantilism, and it was later shown by indirect endocrine studies and by laparoscopy that the origin of the endocrine anomaly and of the lack of secondary sexual characteristics resided in a primary ovarian maldevelopment (Albright, Smith, and Fraser, 1942; Varney, Kenyon, and Koch, 1942) which Wilkins and Fleischmann (1944) termed 'ovarian agenesis'. Albright et al. (1942) had drawn attention to the frequent presence of other associated anomalies, notably coarctation of the aorta. Eight years previously, Ullrich had described similar somatic features (Ullrich, 1930) in an 8-year-old girl who also had congenital lymphoedema, and he collected similar cases in children and young adults of both sexes, both from the literature and from the Munich Children's Hospital. Naturally enough, as a paediatrician, Ullrich had missed the connexion, in a large proportion of girls particularly, between the somatic anomalies and sexual infantilism which Turner later described. Caflisch (1952), stressing the important discriminating criterion of 'hypogonadism', clearly separated, on clinical grounds, Ullrich's syndrome (status) from Turner's, both characterized somatically by bilateral neck webbing, and we have adhered throughout to this clinical dichotomy (Bishop, Lessof, and Polani, 1960; Polani, I96I; Gustavson et al., 1964). Sometimes the double eponym 'Bonnevie-Ullrich's syndrome' (or 'status') has also been used (Emerit et al., 1964) to acknowledge Bonnevie's experimental work and its relation to Ullrich's syndrome (Ullrich, 1937, 1949). Confusion between the two syndromes of Ullrich and Turner, due to their superficial similarity, can arise before the age of puberty, i.e. before sexual infantilism has disclosed itself, and this is specially so in girls, but indirect information can be obtained from sex chromatin (Barr body) and chromosome studies. These can give indirect information, if normal, on the presumptive absence (Ullrich's syndrome in the female) or the presumptive presence, if abnormal, of ovarian dysgenesis (Turner's syndrome in the female) (Polani, 1970). 
It is now known that almost 90 per cent of phenotypic females with the features described by Turner have only one X chromosome, while the rest have various other sex chromosome anomalies. Conversely, patients, both male and female, with the Ullrich syndrome have apparently normal sex chromosomes, $\mathrm{XY}$ and $\mathrm{XX}$ respectively, and a normal sex complement is found also in males with Turner's syndrome. These males, with webbing of the neck and an appearance not unlike that in females with Turner's syndrome or in males and females with the Ullrich syndrome, are distinguished from the males with Ullrich's syndrome by evidence of hypogonadism and/or genital anomaly (for a discussion see Polani, 1969). It was Flavell (1943) who first applied the eponymous description of 'Turner's syndrome in the male' to the neck-webbing syndrome with hypogonadism.

As already stated, the external somatic anomalies of both males and females with Ullrich's syndrome and of males with Turner's syndrome resemble superficially those in females with Turner's syndrome (and dysgenetic ovaries), but the distribution of their cardiac anomalies can be substantially different in the two groups (Bishop et al., 1960; Polani, 1968). In 1963, Noonan and Ehmke described a group of patients with pulmonary valve stenosis, hypertelorism, short stature, mild mental retardation, ptosis, cryptorchidism, and various skeletal malformations; a few of these patients had webbing of the neck but not necessarily pulmonary stenosis (Noonan, 1968). As a result, some workers have used the eponym 'Noonan's syndrome' to describe the conditions that form the subject of this paper, namely Turner's syndrome in males and Ullrich's syndrome in males and females.

In this report we have been concerned only with male and female patients fully investigated by cardiac catheterization and who have features reminiscent of Turner's syndrome in the female but have normal chromosomes. We have collectively referred to these patients as having Ullrich's syndrome We have reviewed the published material on such cases and have added a number of cases of our own.

\section{Review of published reports}

In reviewing the literature, 44 cases of congenital heart disease have been found in patients with somatic features resembling those in Turner's syndrome (and therefore essentially with neck webbing) and normal
TABLE I Details of 44 published cases

\begin{tabular}{|c|c|c|c|}
\hline Diagnosis & $\begin{array}{l}\text { No. of } \\
\text { cases with } \\
\text { lesions }\end{array}$ & $\begin{array}{l}\text { Per cent } \\
\text { of } 44\end{array}$ & $\begin{array}{l}\text { Cases with } \\
\text { lesion alone }\end{array}$ \\
\hline Pulmonary valve stenosis & 33 & 76 & 23 \\
\hline Atrial septal defect & 13 & 30 & 0 \\
\hline Persistent ductus arteriosus & 5 & I I & 3 \\
\hline Ventricular septal defect & 6 & 13 & $\mathbf{I}$ \\
\hline Anomalous pulmonary venous drainage & 2 & 5 & 0 \\
\hline Branch pulmonary stenosis & 2 & 5 & 0 \\
\hline Coarctation of the aorta & $\mathbf{I}$ & $2 \cdot 5$ & $\mathbf{I}$ \\
\hline Fallot's tetralogy & $\mathbf{I}$ & $2 \cdot 5$ & 0 \\
\hline Hypertrophic obstructive cardiomyopathy & $\mathbf{I}$ & $2 \cdot 5$ & $\mathbf{I}$ \\
\hline Subvalvar pulmonary stenosis & $\mathbf{I}$ & $2 \cdot 5$ & $\mathbf{I}$ \\
\hline Mitral incompetence & $\mathbf{I}$ & $2 \cdot 5$ & 0 \\
\hline Aortic stenosis (valve) & $\mathbf{I}$ & $2 \cdot 5$ & 0 \\
\hline Ebstein's anomaly & $\mathbf{I}$ & $2 \cdot 5$ & $\mathbf{I}$ \\
\hline
\end{tabular}

chromosomes (Table I) and for whom there is information from cardiac catheter studies, operation, or necropsy (Halonen, Seppälä, and Hakkila, 1956; Grumbach and Barr, 1958; Chu, Warkany, and Rosenstein, I96I; Futterweit et al., 1961; Caron et al., 1964; Gustavson et al., 1964; Ferrier and Ferrier, 1967; Migeon and Whitehouse, 1967; Celermajer, Bowdler, and Cohen, 1968; Kaplan, Opitz, and Gossett, 1968; Noonan, 1968; Nora and Sinha, 1968; Wright, Summitt, and Ainger, 1968). Of the 44 cases, $23(52 \%)$ had pulmonary valve stenosis and another 10 $(23 \%)$ had other congenital cardiac anomalies in addition, a total of 33 examples $(75 \%)$ of pulmonary valve stenosis. Two patients had pulmonary artery branch stenosis alone. Atrial septal defect was the second most common lesion, with 13 patients (30\%) affected, all of these being combined anomalies, mostly with pulmonary valve stenosis; there were no patients with atrial septal defect alone. Persistent ductus arteriosus occurred 5 times (I I \%), isolated in 3 instances. Ventricular septal defect occurred also in 5 patients ( $11 \%$ ) but never alone. Anomalous pulmonary venous drainage occurred in 2 instances $(5 \%)$ in combination with atrial septal defect and with pulmonary valve stenosis also in one patient. The remaining anomalies each occurred on one occasion in combination with other lesions (Table $\mathrm{I}$ ).

\section{Patient selection}

Clinical material The essential clinical feature for inclusion in the study was the presence of definite webbing of the neck. In addition, there was often short stature, chest deformity, widely spaced nipples, and, usually, intellectual impairment, low hair line, cubitus valgus, and a characteristic facies (Fig.). In a proportion of the males there was evidence of sexual infantilism and/or 
cryptorchidism with or without hypospadias. These patients would be classified as having Turner's syndrome in the male, while the rest would be said to have Ullrich's syndrome.

Out of a total of I02 patients, male and female, referred to the Paediatric Research Unit (P.R.U.) with somatic features resembling those found in females with Turner's syndrome (not all with frank webbing of the neck) but with normal sex chromosomes, there were 79 patients (the list is deposited in the records of the P.R.U.) who fulfilled the above criteria ( 30 males and 49 females). Of these 79 patients, clinical diagnosis of congenital heart disease had been made in 38 cases $(47 \%)$, 18 males $(60 \%)$ and 20 females (40\%). Only 22 cases had been fully investigated by cardiac catheterization (I0 males and 12 females) and they are the subject of the present report.

In order to compare the distribution of different types of congenital heart disease in these patients with that of the general run of patients with congenital heart disease, we have randomly selected three age- and sex-matched controls for ęach patient. All patients in both groups have had cardiac catheterization at the same hospital there are 66 controls in all (Table 2).

\section{Results}

The abnormality found at cardiac catheterization in each of the 22 patients with Ullrich's yndrome is shown in Table 3. The most frequent lesion was stenosis of the pulmonary

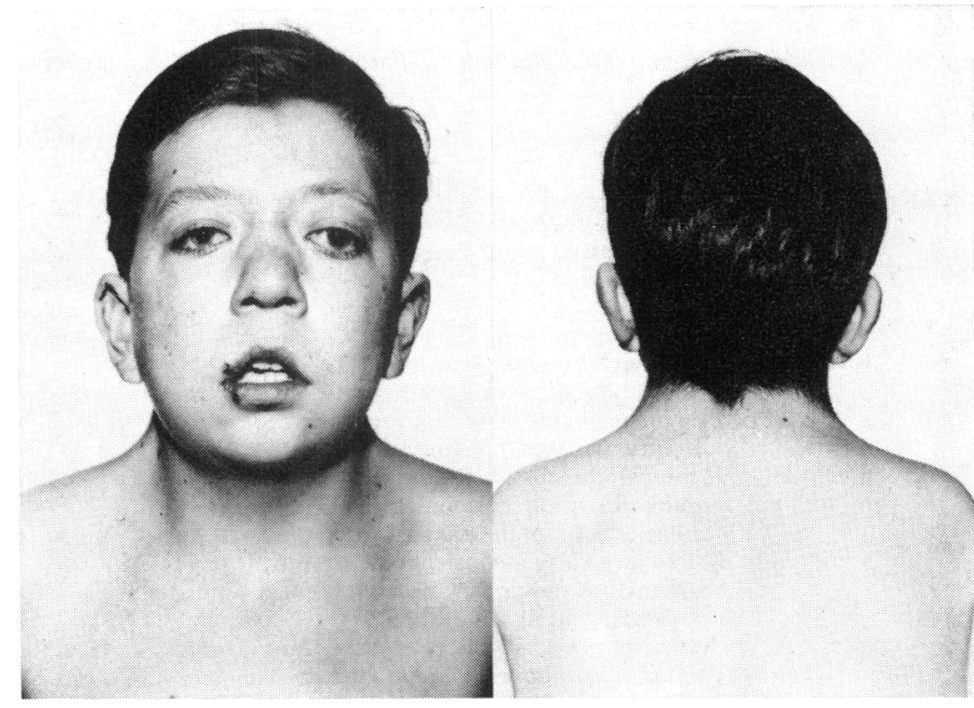

FIG. Ullrich's syndrome in a male (see text).

valve: 9 patients $(45 \%)$ were affected and 5 $(22 \%$ of the total) had no other lesion. Three patients ( $14 \%$ ) had both pulmonary valve stenosis and atrial septal defect. Only $5(7 \%)$ of the control group had pulmonary valve stenosis, and in none was it associated with atrial septal defect. Other lesions that were seen more commonly in the patients with

TABLE 2 Incidence of congenital heart lesions in patients with somatic features of Turner's syndrome (Ullrich's and related syndromes) and in controls

\begin{tabular}{|c|c|c|c|c|c|c|}
\hline \multirow[t]{2}{*}{ Diagnosis } & \multicolumn{3}{|l|}{ Patients } & \multicolumn{3}{|c|}{ Controls } \\
\hline & $\begin{array}{l}\text { Total } \\
\text { No. of } \\
\text { cases } \\
\text { with } \\
\text { lesion }\end{array}$ & $\begin{array}{l}\text { Per cent } \\
\text { of } 22\end{array}$ & $\begin{array}{l}\text { Cases } \\
\text { with } \\
\text { lesion } \\
\text { alone }\end{array}$ & $\begin{array}{l}\text { Total } \\
\text { No. of } \\
\text { cases } \\
\text { with } \\
\text { lesion }\end{array}$ & $\begin{array}{l}\text { Per cent } \\
\text { of } 66\end{array}$ & $\begin{array}{l}\text { Cases } \\
\text { with } \\
\text { lesion } \\
\text { alone }\end{array}$ \\
\hline Atrial septal defect & 5 & 22 & 0 & 13 & 20 & 6 \\
\hline Persistent ductus arteriosus & 5 & 22 & 4 & 8 & 12 & 3 \\
\hline $\begin{array}{l}\text { Ventricular septal defect } \\
\text { Anomalous pulmonary venous }\end{array}$ & 4 & I 8 & I & 25 & 37 & 14 \\
\hline drainage & 2 & 9 & 0 & $\mathbf{I}$ & $I \cdot 5$ & 0 \\
\hline myopathy & 2 & 9 & $\mathbf{I}$ & 0 & 0 & 0 \\
\hline Subvalvar pulmonary stenosis & 0 & 0 & 0 & 2 & 3 & 0 \\
\hline Mitral incompetence & 0 & 0 & 0 & 2 & 3 & $\mathbf{I}$ \\
\hline Aortic stenosis (valve) & 0 & 0 & 0 & 7 & I I & 4 \\
\hline Ebstein's anomaly & 0 & 0 & 0 & I & $\mathbf{I} \cdot 5$ & 0 \\
\hline Corrected transposition & $\mathbf{I}$ & $4: 5$ & 0 & $\mathbf{I}$ & $1 \cdot 5$ & $\mathbf{I}$ \\
\hline Mitral stenosis & $\mathbf{I}$ & 4.5 & 0 & 0 & 0 & 0 \\
\hline Congenital cardiomyopathy & 0 & 0 & 0 & $\mathbf{I}$ & $1 \cdot 5$ & $\mathbf{I}$ \\
\hline Tricuspid atresia & 0 & 0 & 0 & $\mathbf{I}$ & $1 \cdot 5$ & 0 \\
\hline Coronary artery fistula & o & 0 & 0 & $\mathbf{I}$ & $1 \cdot 5$ & $\mathbf{I}$ \\
\hline Pulmonary atresia & 0 & 0 & 0 & 2 & 3 & 2 \\
\hline Complete transposition & 0 & 0 & 0 & 7 & I I & 7 \\
\hline
\end{tabular}


TABLE 3 Congenital heart disease in patients with somatic features of Turner's syndrome and normal sex chromosomes (Ullrich's and related syndromes)

\begin{tabular}{|c|c|c|c|c|}
\hline $\begin{array}{l}\text { Case } \\
\text { No. }\end{array}$ & Age & Sex & Catheter information & Other information \\
\hline $\mathbf{I}$ & 3 wk & $\mathbf{M}$ & $\begin{array}{l}\text { Anomalous pulmonary venous drainage; second- } \\
\text { degree atrial septal defect; persistent ductus } \\
\text { arteriosus }\end{array}$ & $\begin{array}{l}\text { Necropsy: anomalous pulmonary } \\
\text { venous drainage, atrial septal } \\
\text { defect, hypertrophic obstructive } \\
\text { cardiomyopathy, pulmonary valve } \\
\text { stenosis }\end{array}$ \\
\hline 2 & $9 \mathrm{yr}$ & $\mathbf{M}$ & $\begin{array}{l}\text { Pulmonary valve stenosis, grad. } 48 \mathrm{~min} \text {; } \\
\text { infundibular pulmonary stenosis, grad. } 23 \mathrm{~min}\end{array}$ & \\
\hline 3 & $4 \mathrm{yr}$ & $\mathbf{M}$ & $\begin{array}{l}\text { Persistent ductus arteriosus; mitral stenosis; } \\
\text { ventricular septal defect }\end{array}$ & \\
\hline 4 & $6 \mathrm{yr}$ & $\mathrm{F}$ & $\begin{array}{l}\text { Hypertrophic obstructive cardiomyopathy; } \\
\text { subvalvular aortic stenosis, grad. 103 min; } \\
\text { infundibular pulmonary stenosis, grad. } 12 \text { min }\end{array}$ & \\
\hline 5 & $4 \mathrm{yr}$ & $\mathbf{M}$ & $\begin{array}{l}\text { Pulmonary valve stenosis, grad. } 20 \mathrm{~min} \text {; } \\
\text { anomalous pulmonary venous drainage; } \\
\text { secondary atrial septal defect }\end{array}$ & \\
\hline 6 & $19 \mathrm{yr}$ & $\mathbf{F}$ & $\begin{array}{l}\text { Pulmonary valve stenosis, grad. } 50 \mathrm{~min} \text {; } \\
\text { small secundum atrial septal defect }\end{array}$ & Operated; pulmonary valve stenosis \\
\hline 7 & $6 \mathrm{yr}$ & $\mathrm{F}$ & $\begin{array}{l}\text { Persistent ductus arteriosus with right-to-left } \\
\text { shunt of } 1 \cdot 5: 1\end{array}$ & \\
\hline 8 & IO yr & $\mathbf{F}$ & $\begin{array}{l}\text { Pulmonary valve stenosis, grad. } 20 \mathrm{~min} \text {; } \\
\text { small secundum atrial septal defect, and } \\
\text { corrected transposition }\end{array}$ & \\
\hline 9 & $5^{\frac{1}{2}} \mathrm{yr}$ & $\mathbf{F}$ & Coarctation of aorta; small ventricular septal defect & \\
\hline 10 & $4 \mathrm{yr}$ & $\mathbf{M}$ & Congenital aortic incompetence & \\
\hline I I & $4 \mathrm{yr}$ & $\mathbf{F}$ & Persistent ductus arteriosus & Operated \\
\hline 12 & $3 \mathrm{yr}$ & $\mathbf{M}$ & Coarctation of aorta & Operated \\
\hline 13 & I yr & $\mathbf{M}$ & $\begin{array}{l}\text { Coarctation of aorta; anomalous right subclavian } \\
\text { artery }\end{array}$ & Operated \\
\hline 14 & I3 yr & $\mathbf{F}$ & Persistent ductus arteriosus & Operated \\
\hline 15 & $7 \mathrm{yr}$ & $\mathbf{F}$ & Coarctation of aorta & Operated \\
\hline 16 & $2 \mathrm{yr}$ & $\mathbf{F}$ & Pulmonary valve stenosis, grad. $25 \mathrm{~min}$ & \\
\hline I7 & I yr & $\mathbf{F}$ & Ventricular septal defect, small & \\
\hline 18 & $4 \mathrm{yr}$ & $\mathbf{F}$ & $\begin{array}{l}\text { Pulmonary valve stenosis, grad. } 30 \mathrm{~min} \text {; large } \\
\text { ventricular septal defect }\end{array}$ & \\
\hline 19 & $42 \mathrm{yr}$ & $\mathbf{M}$ & Pulmonary valve stenosis, grad. $120 \mathrm{~min}$ & Operated \\
\hline 20 & I9 yr & $\mathbf{M}$ & Pulmonary valve stenosis, grad. $55 \mathrm{~min}$ & $\begin{array}{l}\text { Operated; subsequently developed } \\
\text { infundibular pulmonary stenosis }\end{array}$ \\
\hline 21 & $9 \mathrm{yr}$ & $\mathbf{M}$ & $\begin{array}{l}\text { Pulmonary valve stenosis, grad. } 45 \mathrm{~min} \text {; } \\
\text { second degree atrial septal defect }\end{array}$ & \\
\hline 22 & $23 \mathrm{yr}$ & $\mathbf{M}$ & Pulmonary valve stenosis, grad. $70 \mathrm{~min}$ & Operated \\
\hline
\end{tabular}

Grad. = gradient.

Ullrich's syndrome than in the controls were anomalous pulmonary venous drainage $(9 \%$ against $\mathrm{I} \cdot 5 \%$ ), persistent ductus arteriosus $(22 \%$ against $12 \%)$, coarctation of the aorta (18\% against $6 \%$ ), and hypertrophic obstructive cardiomyopathy ( $9 \%$ against $\% \%)$. The lesions that were less common in the patients than in the control group were ventricular septal defect (18\% in patients against $37 \%$ in controls), congenital aortic stenosis $(0 \%$ against II \%), and Fallot's tetralogy ( $\% \%$ against $I 1 \%$ ). The difference in incidence of these lesions, taken as a whole, between the two groups is significant at well over the $0.1 \%$ level.

One patient who died at the age of 3 weeks had a complex congenital heart lesion with anomalous pulmonary venous drainage from the upper and middle lobes of the right lung to the right atrium and a large primum atrial septal defect. The mitral and pulmonary valve cusps were nodular and the myocardium of both ventricles showed very considerable hypertrophy.

\section{Discussion}

It is clear, both from our own cases and from a review of the reports, that pulmonary valve stenosis is the lesion most frequently seen in patients with Ullrich's syndrome, namely with features of Turner's syndrome and normal chromosomes. Pulmonary valve stenosis is often associated with secundum atrial septal defect. Persistent ductus arteriosus is also frequently seen. Congenital heart disease appears to be more frequent in patients with Ullrich's syndrome $(47 \%$ with a clinical 
diagnosis of heart disease in the present series; $48 \%$ reported by Chaves-Carballo and Hayles, 1966) than in 45,X Turner's syndrome (22\%, Vernant et al., 1966; Polani, 1968). Coarctation of the aorta is much less common than in $45, \mathrm{X}$ Turner's syndrome, in which it seems to be by far the commonest cardiovascular anomaly in older survivors, but does occur occasionally in patients with normal chromosomes and the features of Turner's syndrome.

Ventricular septal defect is relatively uncommon in patients with Ullrich's syndrome, but both anomalous pulmonary venous drainage and hypertrophic obstructive cardiomyopathy occur rather more often than in control patients.

It seems also that differences exist in the proportion with which cardiac affection is found in the two sexes with the syndromes under discussion (Polani, 1968).

Neither the aetiology of Ullrich's syndrome, with normal chromosomes, nor the aetiology of the associated congenital heart disease is known. Matolcsy (1936) described briefly the occurrence of severe webbing in sibs, one of them a boy of 13 years with cryptorchidism, and Rossi and Howald (1947) described the kinship and sibship occurrence of 'status Bonnevie-Ullrich', the Ullrich syndrome. It is now realized that, while the majority of examples of Ullrich's syndrome in males and females are sporadic, there are examples of parent-to-child transmission (Nora and Sinha, 1967, 1968; Polani, Angell, and Polani, 1967) and not only from mother to daughter. These suggest autosomal dominant inheritance, and there are sibship examples suggesting autosomal recessive transmission (Alslev and Reinwein, 1958; Solis and Schwartz, 1951; Opitz, Sarto, and Summitt, 1966; Migeon and Whitehouse, 1967; Polani et al., 1967). There are also examples related to an autosomal structural anomaly (Polani et al., 1967; Polani, 1969). While some of the sporadic cases, in addition to being sporadic examples of familial disorders, may well be phenocopies and others, perhaps, new 'point' mutations, the probability exists that some examples may result from undetected chromosome mutations.

The patients were referred to the Paediatric Research Unit by many physicians and surgeons, too numerous to acknowledge individually. We hope that they will accept this collective acknowledgment of our indebtedness to them.

We respectfully dedicate this paper to Maurice Campbell on his 8oth birthday; and Paul Polani recalls with pleasure and gratitude his close research association with him and records his indebtedness to him for his teachings and many personal kindnesses.

\section{References}

Albright, F., Smith, P. H., and Fraser, R. (1942). A syndrome characterized by primary ovarian insufficiency and decreased stature. Report of II cases with a digression on hormonal control of axillary and pubic hair. American fournal of the Medical Sciences, 204, 625.

Alslev, J., and Reinwein, H. (1958). Úber das familiäre Vorkommen des sogenannten Ullrich-TurnerSyndroms und das Vorhandensein eines Pterygium colli, eines Kryptorchidismus und des MeigeSyndroms bei zwei Brüdern mit kongenitalen Vitien. Deutsche medizinische Wochenschrift, 83, 601 .

Bishop, P. M. F., Lessof, M. H., and Polani, P. E. (I960). Turner's syndrome and allied conditions. In Sex Differentiation and Development, p. I62. (Memoirs of the Society for Endocrinology, No. 7.) Ed. by C. R. Austin. Cambridge University Press.

Caflisch, A. (1952) Das Pterygium. M.D. Thesis, University of Zürich.

Caron, P., Mieher, W. C., Mellinger, R. C., and Green, E. W. (1964). Turner's syndrome in males. Henry Ford Hospital Medical Bulletin, 12, 121.

Celermajer, J. M., Bowdler, J. D., and Cohen, D. H. (1968). Pulmonary stenosis in patients with the Turner phenotype in the male. American fournal of Diseases of Children, 116, 351.

Chaves-Carballo, E., and Hayles, A. B. (1966). Ullrich-Turner syndrome in the male: review of the literature and report of a case with lymphocytic (Hashimoto's) thyroiditis. Mayo Clinic Proceedings, 41, 843.

Chu, E. H. Y., Warkany, J., and Rosenstein, R. B. (196I). Chromosome complement in a case of the 'male Turner syndrome'. Lancet, $1,786$.

Emerit, I., De Grouchy, J., Corone, P., Vernant, P., and Laval-Jeantet, M. (1964). Agénésie sacrococcygienne et syndrome de Bonnevie-Ullrich. Acta Geneticae Medicae et Gemellologiae, 13, 69.

Ferrier, P. E., and Ferrier, S. A. (1967). Turner's phenotype in the male. Pediatrics, 40, 575.

Flavell, G. (1943). Webbing of the neck, with Turner's syndrome in the male. British fournal of Surgery, 31, 150.

Futterweit, W., Chapman, M. L., Salvaneschi, J. P., and Moloshok, R. E. (196I). Multiple congenital defects in a twelve year old boy with cryptorchidism - 'male Turner's syndrome'. Metabolism, 10, 1074 .

Grumbach, M. M., and Barr, M. L. (1958). Cytologic tests of chromosomal sex in relation to sexual anomalies in man. In Recent Progress in Hormone Research, vol. I4, p. 255. Ed. by G. Pincus. Academic Press, New York.

Gustavson, K.-H., Hagberg, B., Knutson, H., and Sjölin, S. (1964). The pterygium-colli syndrome in the male: A clinical, histological, and cytogenetic study of two cases. Acta Paediatrica (Stockholm), 53, 454 .

Halonen, P. I., Seppälä, T., and Hakkila, J. (1956). Turner's syndrome in a man. Acta Medica Scandinavica, 153, 427.

Kaplan, M. S., Opitz, J. M., and Gossett, F. R. (1968). Noonan's syndrome. A case with elevated serum alkaline phosphatase levels and malignant schwannoma of the left forearm. American fournal of Diseases of Children, 116, 359. 
Matolcsy, T. (1936). Ubber die chirurgische Behandlung der angeborenen Flughaut. Archiv für klinische Chirurgie, 185, 675.

Migeon, B. R., and Whitehouse, D. (1967). Familial occurrence of the somatic phenotype of Turner's syndrome. fohns Hopkins Medical fournal, 120, 78.

Noonan, J. A. (1968). Hypertelorism with Turner phenotype. A new syndrome with associated congenital heart disease. American fournal of Diseases of Children, 116, 373.

Noonan, J. A., and Ehmke, D. A. (1963). Associated noncardiac malformations in children with congenital heart disease. Fournal of Pediatrics, 63, 468.

Nora, J. J., and Sinha, A. K. (1967). Hereditary Turner phenotypes. Lancet, 2, 256.

Nora, J. J., and Sinha, A. K. (I968). Direct familial transmission of the Turner phenotype. American fournal of Diseases of Children, 116, 343.

Opitz, J. M., Sarto, G. E., and Summitt, R. L. (1966). Turner's syndrome and phenotype. Lancet, $2,282$.

Polani, P. E. (196I). Turner's syndrome and allied conditions. British Medical Bulletin, 17, 200.

Polani, P. E. (1968). Chromosomal abnormalities and congenital heart disease. Guy's Hospital Reports, $117,323$.

Polani, P. E. (1969). Turner phenotype with normal sex chromosomes. Birth defects: original article series, 5, Clinical delineation of birth defects Pt. 5, 24.

Polani, P. E. (1970). Chromosome phenotypes - sex chromosomes. In Congenital Malformations. Proceedings of the Third Internationol Conference on Congential Malformations, The Hague, September 1969 , p. 233. Ed. by F. C. Fraser and V. A. McKusick. Excerpta Medica International Congress Series No. 204.

Polani, P. E., Angell, R., and Polani, N. (1967). Ullrich's syndrome. Lancet, 2, $42 \mathrm{I}$.

Rossi, E., and Howald, E. (1947). Úber die Erblichkeit des Status Bonnevie-Ullrich. Helvetica paediatrica acta, 2, 98 .
Solis, J., and Schwartz, M. M. (195I). Sindrome de gonadas rudimentarias, baja estatura, cuello corto, y cubitus valgus. Revista Médica de Rosario, 4I, 222.

Turner, H. H. (1938). A syndrome of infantilism, congenital webbed neck, and cubitus valgus. Endocrinology, 23, 566 .

Ullrich, O. (1930). Uber typische Kombinationsbilder multipler Abartungen. Zeitschrift für Kinderheilkunde, 49, $27 \mathrm{I}$.

Ullrich, O. (1937). Zur Phänogenese kombinierter Missbildungen. Monatsschrift für Kinderheilkunde, 68, 94 .

Ullrich, O. (1949). Turner's syndrome and Status Bonnevie-Ullrich: A synthesis of animal phenogenetics and clinical observations on a typical complex of developmental anomalies. American fournal of Human Genetics, 1, 179.

Varney, R. F., Kenyon, A. T., and Koch, F. C. (1942). An association of short stature, retarded sexual development and high urinary gonadotropin titers in women. Fournal of Clinical Endocrinology and Metabolism, 2, 137.

Vernant, P., Corone, P., De Grouchy, J., De Gennes, J.-L., and Emerit, I. (1966). Le coeur dans le syndrome de Turner-Ullrich. (Étude de 26 cas personnels et revue des observations comportant une étude chromosomique.) Archives des Maladies du Coeur et des Vaisseaux, 59, 850.

Wilkins, L., and Fleischmann, W. (1944). Ovarian agenesis: Pathology, associated clinical symptoms and the bearing on the theories of sex differentiation. Fournal of Clinical Endocrinology and Metabolism, 4,357 .

Wright, N. L., Summitt, R. L., and Ainger, L. E. (1968). Noonan's syndrome and Ebstein's malformation of the tricuspid valve. American fournal of Diseases of Children, 116, 367.

Requests for reprints to Professor Paul E. Polani, Cameron House, Guy's Hospital, London S.E.I. 